\title{
Challenges Faced by Small and Micro Enterprises in Sri Lanka
}

\author{
Kahadawa Appuhamilage Sucharitha Navarathne \\ Postgraduate Institute of Agriculture, University of Peradeniya, Peradeniya, Sri Lanka
}

Email address:

suchnavarathne@gmail.com

\section{To cite this article:}

Kahadawa Appuhamilage Sucharitha Navarathne. Challenges Faced by Small and Micro Enterprises in Sri Lanka. Urban and Regional Planning. Vol. 2, No. 6, 2017, pp. 34-37. doi: 10.11648/j.urp.20170206.11

Received: October 27, 2017; Accepted: November 8, 2017; Published: December 25, 2017

\begin{abstract}
Small and micro enterprises play a significant role in most economies, whether developed or developing. However, in developing countries these enterprises have tended to be looked at from a development, or poverty alleviation perspective, rather than as entrepreneurial activities and potentially growing businesses. This paper presents a study of a group of small and micro entrepreneurs in Sri Lanka from an entrepreneurship perspective rather than a development one. The purpose of this paper is to document the challenges faced by group of successful small and micro entrepreneurs in Sri Lanka, who received micro-financing to establish or grow their micro-enterprises and to examine these enterprises in terms of their potential for long term success. Case study approach was adopted as the methodology of the study to gain a holistic understanding in a given context. The identified challenges in the given context were maintaining higher quality of product and services, upgrading the technology, business rules and regulations related issues, competition issues and infrastructure issues. The successful small and micro entrepreneurs already believe that they are successful - but still have aspirations to grow further.
\end{abstract}

Keywords: Challenges, Small and Micro Enterprises, Micro Financing

\section{Introduction}

Small and micro enterprises play a significant part in most economies, whether developed or developing. However, in developing countries these enterprises have tended to be looked at from a development, or poverty alleviation perspective, rather than as entrepreneurial activities and potentially growing businesses. This paper presents a study of a group of micro entrepreneurs in Sri Lanka from an entrepreneurship perspective rather than a development one.

The purpose of this paper is to document the activities of a group of micro-entrepreneurs in Aththanagalla division which is situated in Western province in Sri Lanka, who received micro financing to establish or grow their micro enterprises and to examine these enterprises in terms of their potential for long term success. This process itself offered many challenges, as did identifying the commonalities between enterprises in the developed world and enterprises entered into for largely survival reasons that have no access to basic services. Exploring indicators of success in this context highlights interesting differences and identifies others that may or may not be relevant in a different context.

Small scale industries play a major role to create an economic environment in Sri Lanka [1]. Samurdhi is such a programme with a component of entrepreneurship development [2]. "Mihijaya" is loan scheme operated by Samurdhi bank with the aim of facilitating entrepreneurship development among Samurdhi beneficiary families since 2007 [3].

It is evident that all who obtained the loan have not been able to successfully carryout their businesses and only a minority has been able to successfully carryout their business operations (Pilot study). In such a context, this research aims to study the extent of issues faced by the successful small and micro enterprises.

\section{Literature Review}

\subsection{Micro Enterprises in Developing Nations}

The poor, unable to find paid employment, were setting up their own small businesses outside the formal sector, in cities 
and in rural areas [4]. Microenterprise development (MED) programmes have been a popular poverty alleviation strategy in developing nations for many years. Indeed, the existence of policies to promote textile production by Indian micro entrepreneurs was reported as early as 1947 [5] the very time at which attention of developed world policymakers first turned to relieving poverty in the world's poorest nations [6].

Micro-enterprises are typically defined as very small, informally run businesses, involved in activities other than crop production. A distinction may be made between survival microenterprises, low skilled, low-cost, low return activities, and entrepreneurial microenterprises, which tend to require more skills on the part of the business owner and a greater use of capital and technology in production [7].

Entrepreneurship define as "the process of creating something new with value by devoting the necessary time and effort, assuming the accompanying financial, psychic, and social risks, and receiving the resulting rewards of monetary and personal satisfaction and independence [8]. They go on to identify a number of types of start-ups including lifestyle firm, a small venture that supports the owners and usually does not grow, foundation company - a type of company formed from research and development and usually does not go public and a high potential venture - a venture that has high growth potential and therefore receives great investment interest.

The distinction between survival and entrepreneurial micro-enterprises - it seems that entrepreneurship is required for either type of micro-enterprise [7]. The difference may be in the motivation rather than the activities engaged in. This suggests that 'survival' micro-enterprises might have the potential to grow and contribute in a greater way than mere survival of the owner and his/her family.

\subsection{Micro Finance}

A micro-entrepreneur requires capital for two main business reasons: to fund the start-up of the business, and to fund further business growth. A number of factors can and do hamper attempts by the poor to secure business finance. Saving even small amounts of money can be difficult for the poor, given their very low levels of income. However, a greater obstacle to saving in developing countries may be the inability to access safe deposit facilities for accumulating funds, since savings facilities are commonly limited in number and geographic dispersion in these nations [9]. Without a store of funds to protect them, the poor become particularly vulnerable to exogenous shocks that draw on household resources (for instance a failed crop or illness in the family). This vulnerability is a contributing factor to the high levels of risk aversion exhibited by the poor, which in turn may deter them from seeking loans to start a business.

Microcredit institutions are usually willing to loan in small amounts and to those without collateral. The poor may selfexclude due to their high risk aversion as noted above, or the 'product' on offer from the micro-credit institution may fail to meet the needs of the poorest members of the community [10].

\subsection{Micro Finance in Sri Lanka}

Several government ministries and institutions in Sri Lanka have launched some development activities that have entrepreneurship components [11] and Samurdhi is such a programme with a component of entrepreneurship development [2]. Assistance provided by the Samurdhi authority to small scale entrepreneurs include low interest bank loans provided through the Samurdhi bank for engaging in self-employment activities, training provided on skill development and facilities made for them to obtain machinery and raw materials from chapter sources [12]. "Mihijaya" is loan scheme operated by Samurdhi bank with the aim of facilitating entrepreneurship development among Samurdhi beneficiary families since 2007 [3].

\section{Methods}

The study was undertaken in fifteen Grama Niladari divisions situated in Aththanagalla division of Sri Lanka. Population was consisted with the list of Samurdhi beneficiary families (54 families) residing in the study site who took "Mihijaya" loans from Bemmulla Samurdhi Bank Society in Atthanagalla division in year 2008.

To achieve the basic aim of the research it was necessary to observe the successful businesses after seven year period of time in year 2014. The scale for Measurement of success was based on a study of scales used by Lakshamana Rao [13]. The performance of the unit of each respondent was rated on each of these variables on a 3 point scale and resulted (a) Economically successful businesses - 18 and (b) Economically unsuccessful businesses -36 .

\subsection{Case Study Approach and Importance of Studying Processes}

The case study approach was considered as the appropriate methodology for collection and analysis of data as it provides a wide range of information gathering techniques [14]. As the research objectives necessitated the investigation to carry out an assessment of challenges faced by successful Samurdhi loan takers/business operators, this was achieved by studying the process of activities over a period of time in year 2014 .

\subsection{Data Collection and Analysis}

Pilot study of the study resulted that three were successful and five were less successful. The pilot study revealed that everybody who obtained the loan have not been able to successfully carryout their businesses and only minority have been able to achieve such success. Primary sources of data such as in-depth interviews guided by a topic guide and direct / participant observations were used. Secondary data on Mihijaya loan report of Bemmulla Samurdhi Bank Society in year 2010 was also used to establish the context. These multiple data sources helped in triangulating the findings [14]. Finally, within and cross case analysis of data were carried out. 


\section{Discussion}

The structure of the market within which microenterprises operate can impact upon their performance in both developed and developing countries. Barriers to market entry can include registration or licensing fees, highly differentiated production, and/or capital-intensive production methods, expertise, infra-structure. Many of these barriers tend to be low in the informal economy since in these markets, production tends to be labour intensive, adding little value, requiring little fixed capital investment and not requiring formal registration of business [7]. All of the entrepreneurs interviewed were operating in the informal sector at the time of interview.

On the positive side, low market entry barriers enable micro entrepreneurs to be responsive to changing demand conditions [15]. However, the disadvantages to operating in such markets are far more significant. As a result of the ease of entry into such markets, they tend to be overcrowded and highly competitive [16]. Returns on production are low, and markets highly volatile [17]. Sellers have no market power demand is highly price elastic and attempts to raise prices will drive customers toward lower priced competitors.

The effects of low barriers to entry described above can be amplified in a situation of isolated markets [18]. Not only are these producers faced with a limited market but also the market is small to start with. With adequate transport and access to nearby markets micro-entrepreneurs may not be faced with highly elastic demand curves. However, isolated markets lack access to transport and other forms of infrastructure required for successful microenterprise operation [7]. Microenterprises without access to high voltage electricity have one more obstacle to their introducing enhanced productivity enhancing technologies. With the exception of the garments wholesaler they were using public transport which is very time consuming and takes time away from the business.

\section{Conclusions}

It is apparent from the nature of the businesses and their response to some of the questions that the entrepreneurs interviewed are successful entrepreneurs. Many of the entrepreneurs have plans to move beyond this stage with enhancing the ideas and the resource they will need to grow.

The successful entrepreneurs have gone, and continue to go, through the process of creating something new with value by devoting the necessary time and effort, assuming the accompanying financial, psychic, and social risks, and receiving the resulting rewards of monetary and personal satisfaction and independence.

The successful small and micro entrepreneurs already believe that they are successful - but still have aspirations to grow further. They appear to prefer to have their economic well-being in their hands, rather than those of an employer. Most of the respondents identified the need for more knowledge to be able to grow and the lack of external stimulus may well slow down the rate of innovation, as the lack of good infrastructure and access to finance may slow down and restrict their growth potential.

\section{References}

[1] Kanagasingam, R. (2012). Entrepreneurship in Sri Lanka, Daily FT, http://www.ft.lk/2012/08/23/entrepreneurship-insri-lanka/.

[2] National Enterprise Development Authority (2015), "Strategies 07. 6," http://www.neda.lk/index.php/en/component/content/article/1 01 .

[3] Bank Society Guideline-20 (2007). Mihijaya -Special Loan Programme.

[4] McGuire, P. B. and J. Conway (2001), The Microfinance Phenomenon, Foundation for Development Cooperation, Brisbane.

[5] McPherson, M. A. (1996), 'Growth of micro and small enterprises in southern Africa', Journal of Development Economics, vol. 48, p. 253-277.

[6] Toye, J. (1993), Dilemmas of Development, Blackwell Press, Oxford.

[7] Shaw, J. (2004), 'Microenterprise Occupation and Poverty Reduction in Microfinance Programs: Evidence from Sri Lanka', World Development, vol. 32, no. 7.

[8] Hisrich and Peters (1998) Entrepreneurship (4 $4^{\text {th }}$ Edition) Boston. McGraw Hill.

[9] Rutherford, S. (2000), 'Raising the Curtain on the "Microfinancial Services Era"', Focus Notes, No. 15, Consultative Group to Assist the Poorest, World Bank, Washington.

[10] Mwenda, Kenneth Kaoma \& Muuka, Gerry Knombo (2004) 'Towards best practice for micro finance institutional engagement in African rural areas: Selected cases and agenda for action." International Journal of Social Economics. Bradford: 2004. vol 31, Iss. 1/2 pg. 143.

[11] Tissera, D. (2008). Entrepreneurship: A Necessary Skill for All Youth, National Conference on Graduate Entrepreneurship 24, BMICH.

[12] Media Center for National Development of Sri Lanka (2013). Ministry of Mass Media and Information Sri Lanka, $\mathrm{http}: / /$ development.lk/news.php?news=254.

[13] Rao, V. L. (1986). Industrial Entrepreneurship in India, Chaugh.

[14] Yin, R. K., (1984). Case Study Research: Design and Methods, $\left(2^{\text {nd }} e d\right)$, Sage.

[15] Versluysen, E. (1999), 'Self-Employment: A Cure for Poverty?' in Defying the Odds: Banking for the Poor, Kumarian Press, West Hartford.

[16] Barton, C. (1997), Microenterprise Business Development Services: Defining Institutional Options and Indicators of Performance, Microenterprises Best Practice Project, USAID, Washington DC. 
[17] Asian Development Bank (ADB, 1997), Microenterprise Development: Not By Credit Alone, Asian Development Bank, Manila.
[18] Snodgrass, D., (1996), The Economic, Policy and Regulatory Environment, Microenterprise Impact Project, USAID, Washington. 